\section{Configuration of the parameters for scanner-based track detector evaluation system}

\begin{abstract}
According to the new European Union Basic Safety Standards (EU-BSS), preparation of the National Radon Action Plan is obligatory for the Member States. One of the plan's aims is to carry out an indoor radon survey to identify radon-prone areas. In the radon surveys, track detector methods are used. At the University of Pannonia (Veszprém, Hungary), a new scanner-based detector evaluation system has been developed. For the application of the new system, the selection of appropriate parameters is necessary. In this study, selection of the applied track detectors and setting of the etching conditions have been carried out. Two different types of allyl diglycol carbonate (ADC or CR-39) track detectors were investigated, taking into account the detector's background and response during the exposure (determination of calibration factor). The Baryotrak's background track density $\left(0-1.5\right.$ tracks $\left.\cdot \mathrm{mm}^{-2}\right)$ was lower than that of the $0.8-4$ tracks $\cdot \mathrm{mm}^{-2}$. The response of the Tastrak was higher, but the deviation of the calibration factor was much higher $\left(1.2-5.3 \times 10^{-3}\right.$ tracks $\left.\cdot \mathrm{mm}^{-2} /\left(\mathrm{Bq} \cdot \mathrm{day} \cdot \mathrm{m}^{-3}\right)\right)$ than in the case of the Baryotrak $\left(1.4-2.8 \times 10^{-3}\right.$ tracks. $\mathrm{mm}^{-2} /\left(\mathrm{Bq} \cdot\right.$ day $\left.\left.\cdot \mathrm{m}^{-3}\right)\right)$. After the systematic review of the etching system, a new method was developed. For the determination of the optimal track diameter, the argon fluoride (ArF) laser was applied to create tracks with diameters in the range of 10-100 $\mu \mathrm{m}$. The optimum track size was in the range of 40-60 $\mu \mathrm{m}$. On this basis, new etching conditions were determined: $6.25 \mathrm{M} \mathrm{NaOH}$ solution, a temperature of $90^{\circ} \mathrm{C}$, and time period of 8 hours.
\end{abstract}

Keywords: Background track density $\bullet$ CR-39 • Etching conditions • Indoor radon • Sensitivity for radon

\section{Introduction}

Rn-222 (radon) and its decay products contribute the highest to the radiation doses for people, mostly due to elevated concentrations indoors (in dwellings). The concentration of Rn-222 varies over a wide range all over the world [1]. The sources of indoor radon are mainly the soil [2-5] and building materials $[6,7]$, occasionally including tap water $[8$, 9] and natural gas [10].

According to the new European Union Basic Safety Standards (EU-BSS) [11], the Member States have to prepare a National Radon Action Plan about the handling of the "radon problem". One of the Plan's aims is to identify the radon-prone areas in their own countries. Therefore, the radon survey has to be carried out in Hungary, too.

In the past decades, there were several indoor radon surveys in Hungary. The first survey was performed between 1985 and 1988 in 122 dwellings. The average radon concentration was estimated as $55.2 \mathrm{~Bq} \cdot \mathrm{m}^{-3}$ [12]. In 1993-1994, radon measurements were carried out in about 1000 homes. The average radon concentration was $128 \mathrm{~Bq} \cdot \mathrm{m}^{-3}$. In $16 \%$ of the measurement points, the radon concentration 
was $>200 \mathrm{~Bq} \cdot \mathrm{m}^{-3}$ and, in $1.5 \%$ cases, the radon levelwas $>600 \mathrm{~Bq} \cdot \mathrm{m}^{-3}[13]$, which was the recommended action level at that time [14]. The largest Hungarian survey was conducted between 1994 and 2004 in 15277 buildings. The estimated annual average indoor radon concentration was $62 \mathrm{~Bq} \cdot \mathrm{m}^{-3}[15]$.

At the Institute of Radiochemistry and Radioecology, University of Pannonia (IRR-UP) also, some indoor radon surveys were carried out. Szeiler et al. [16] measured the radon concentration in 80 homes and workplaces in 2011-2012. The average value was $79 \mathrm{~Bq} \cdot \mathrm{m}^{-3}$, and all values were $<200 \mathrm{~Bq} \cdot \mathrm{m}^{-3}$, except for one measurement point. Furthermore, there were measurements of radon and thoron in dwellings within joint projects in the Visegrad countries (Poland, Slovakia, Czech Republic, and Hungary). These were carried out in 156 buildings, including homes and workplaces $[17,18]$ and kindergartens [19]. During these surveys, an old evaluation system was used for the measurements, which was very slow and obsolete as it was based on the visual counting of tracks through a microscope. This system was not appropriate for the evaluation of the large number of detectors. Some years ago, a new, scanner-based system was developed, which was faster and modern.

The aim of this study was to check the measurement protocol of track detectors at the IRR-UP to optimize the parameters of the new system.

\section{Materials and methods}

\section{Track detector}

The most current types of track detectors are the CR-39 (allyl diglycol carbonate) and LR-115 (cellulose nitrate). For the new system, the CR-39 detector was selected because of its transparency, which was necessary for the scanner. In this study, two CR-39 detectors from different manufacturers (Tastrak - Track Analysis Systems Ltd, Great Britain; and Baryotrak - Fukuvi Chemical Ltd, Japan) were used and compared with each other, taking into account the detectors' backgrounds and sensitivity levels. The standard size of each detector was $1 \mathrm{~cm}$ $\times 1 \mathrm{~cm} \times 0.1 \mathrm{~cm}$.

\section{Background track density of the track detectors}

The first test was to check the possible increase of the background track density during the storage period. At the beginning of the test, 24 CR-39 detectors of each type were enclosed in a radon-tight foil. Twelve detectors were stored in the laboratory at room temperature, and the other 12 were stored in the refrigerator at $5^{\circ} \mathrm{C}$. Every month, one detector from each group was taken for analysis, and, after etching, both detectors were evaluated by an optical microscope system to determine the background track density. At the beginning of the test, the background track density was determined in the case of a new detector by the same method. On the basis of these values, the detection limits were calculated.

\section{Detector's response to radon}

Similar to the background test, 24 detectors were prepared for storage. Every month, one detector from each group was taken out and exposed in the radon chamber. The radon concentration was stable during each exposure, but the exposures varied between $3600 \mathrm{~Bq} \cdot$ day $\cdot \mathrm{m}^{-3}$ and $4200 \mathrm{~Bq} \cdot \mathrm{day} \cdot \mathrm{m}^{-3}$ for particular ones. After each exposure, the detectors were etched and evaluated by the optical microscope system. At the beginning of the test, the calibration factor was determined in the case of a new detector by the same method. For the estimation of the detectors' response, the calibration factor was used, which was calculated according to Eq. (1):

$$
K=\frac{N_{\text {sample }}-N_{\text {background }}}{E}
$$

where $K$ is calibration factor [tracks $\cdot \mathrm{mm}^{-2} /$ $\left(\mathrm{Bq} \cdot\right.$ day. $\left.\left.\mathrm{m}^{-3}\right)\right], N_{\text {sample }}$ is the track density of the exposed detector [tracks $\mathrm{mm}^{-2}$ ],$N_{\text {background }}$ is the track density of the background [tracks. $\mathrm{mm}^{-2}$ ], and $E$ is the radon exposure in the chamber for the particular exposure $\left[\mathrm{Bq} \cdot \mathrm{day} \cdot \mathrm{m}^{-3}\right]$.

\section{Etching}

In a previous study [20], a special calibration detector with 16 tracks was prepared by using argon fluoride $(\mathrm{ArF})$ laser. The sizes of the tracks were between $10 \mu \mathrm{m}$ and $100 \mu \mathrm{m}$. The special detector was used to determine the optimum track size using the new scanning system. It has been found that the optimal track diameter was $40-60 \mu \mathrm{m}$. To achieve this optimal size of tracks, investigation of the influence of etching parameters was necessary (time of etching, temperature of the bath, and concentrations of $\mathrm{NaOH}$ and chemicals in the solution). In this study, $\mathrm{NaOH}$ concentration was constant $(6.25 \mathrm{M})$, the time varied from 1 hour to 8 hours, while the temperature varied from $60^{\circ} \mathrm{C}$ to $90^{\circ} \mathrm{C}$. Before etching, all the detectors were exposed in the radon chamber; the exposure was equal to $360 \mathrm{kBq} \cdot \mathrm{h}^{-1} \cdot \mathrm{m}^{-3}$. For each etching condition, $10 \mathrm{de}-$ tectors were chosen. Before and after the etching, the total mass of these detectors was determined, and the bulk etch rate $\left(V_{B}\right)$ was determined for each group, according to Eq. (2):

$$
V_{B}=\frac{\Delta m}{2 A \cdot \rho \cdot t}
$$

where $\Delta m$ is the mass difference (in grams), $A$ is the area of the detector surface (in square centimeters), $\rho$ is the density of the detector (in gram per cubic centimeter), and $t$ is etching time (in hours) [21].

In the case of the highest bulk etch rate, the detectors were investigated using a scanning electron microscope (SEM; Philips XL30 ESEM; SEMTech Solution Inc., USA) to determine the tracks' diameters.

There are several studies showing that some mixtures of organic materials (such as different alcohols) can increase the etch velocity $[22,23]$. Based on this 


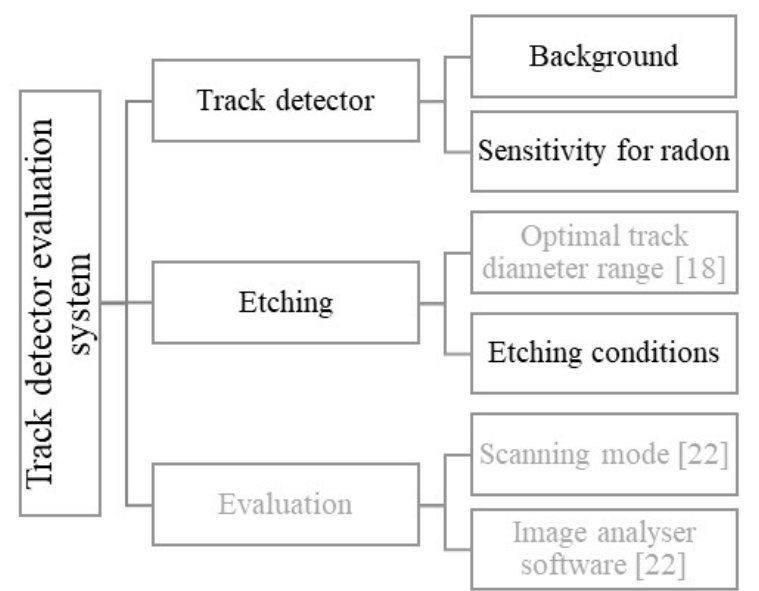

Fig. 1. Flow chart of the optimization procedure for track detector evaluation.

fact, the possibility of reusing the etching solution was investigated in this study, examining whether the dissolved detector's material, such as an organic material, can increase the velocity of etching.

For this test, a "detector material solution" was prepared: 200 detectors were left in $\mathrm{NaOH}$ solution for two weeks. The concentration of the dissolved material of the detector was determined by weighing, and it was estimated to be $3.8 \mathrm{~g} \cdot \mathrm{L}^{-1}$. From this solution, eight different aliquots were taken and added to fresh etching solution, and for each resulting solution, etching was carried out. The $V_{B}$ was determined for each case, according to Eq. (2).

\section{Optimization of the system}

To optimize the whole system of preparation of track detectors for scanning, it was necessary to perform investigations related to several stages of the procedure. The flow chart showing the stages of this procedure is presented in Fig. 1. In this study, the selection of the track detector type and the choice of the etching parameters are described. The optimal range of the track diameter was determined, the detailed procedure of which was described elsewhere [20], and tests of the scanner and development of the new software were the subjects of another study [24].

\section{Results and discussion}

In our investigations, it has been found that the Baryotrak detector's background track density $\left(0-1.5\right.$ tracks $\left.\cdot \mathrm{mm}^{-2}\right)$ is lower than the Tastrak detector's track density $\left(0.8-4\right.$ tracks $\left.\cdot \mathrm{mm}^{-2}\right)$. The average background track densities for Baryotrak and Tastrak were 0.5 track $\cdot \mathrm{mm}^{-2}$ and 1.8 tracks. $\mathrm{mm}^{-2}$, respectively. It means that the difference between the average values was $>300 \%$.

The background track density increased with the time of storage: this rate was $15 \%$ in the case of Baryotrak detectors and 40\% for Tastrak detectors. Any association between the temperature of storage

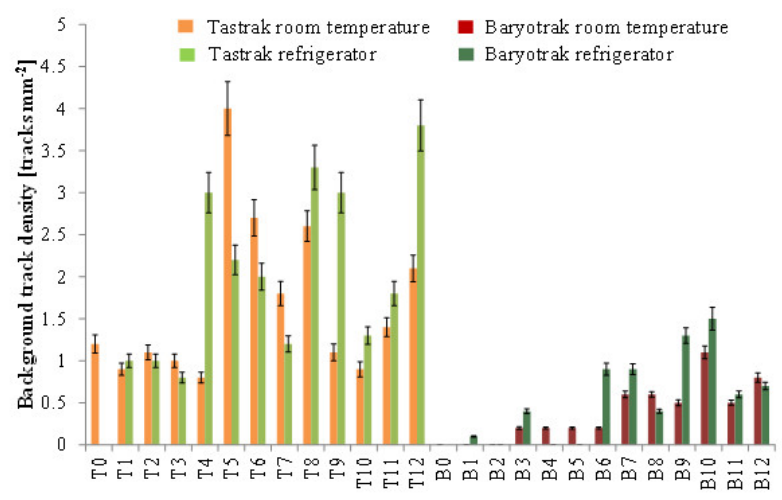

Fig. 2. Fluctuation of the background track density.

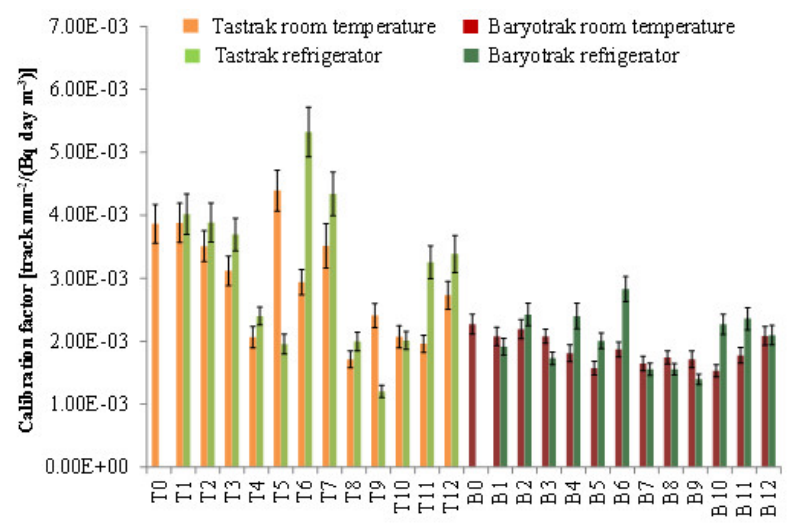

Fig. 3. Fluctuations of the calibration factor.

and changes in the background track density was observed. The fluctuation of the background track density can be seen in Fig. 2.

From the background track density, the lower limit of detection (LLD) was determined for both types of CR-39: it was $250 \mathrm{~Bq} \cdot \mathrm{day} \cdot \mathrm{m}^{-3}$ for Baryotrak and $600 \mathrm{~Bq} \cdot \mathrm{day} \cdot \mathrm{m}^{-3}$ for Tastrak.

It has been determined that the response to radon in the case of the Tastrak detectors was higher, but the deviation of the calibration factor was much higher, i.e., $1.2-5.3 \times 10^{-3}$ tracks. $\mathrm{mm}^{-2} /\left(\mathrm{Bq} \cdot\right.$ day $\left.\cdot \mathrm{m}^{-3}\right)$, than in the case of the Baryotrak detectors, for which it varied only between $1.4 \times 10^{-3}$ and $2.8 \times 10^{-3}$ tracks $\cdot \mathrm{mm}^{-2} /\left(\mathrm{Bq} \cdot\right.$ day $\left.\cdot \mathrm{m}^{-3}\right)$. For further calculations, the following calibration factors were used for the two types of detectors: for Baryotrak, $2.0 \times 10^{-3}$ tracks $\cdot \mathrm{mm}^{-2} /\left(\mathrm{Bq} \cdot\right.$ day $\left.\cdot \mathrm{m}^{-3}\right)$; and for Tastrak, $3.0 \times 10^{-3}$ tracks $\cdot \mathrm{mm}^{-2} /\left(\mathrm{Bq} \cdot\right.$ day $\left.\cdot \mathrm{m}^{-3}\right)$. Any tendency in the fluctuation of the calibration factor was observed. It means that there is no correlation between the temperature of storage and the value of the calibration factor. The changes in the values of the calibration factor during the test can be seen in Fig. 3.

The results of the bulk etch rate investigations were as follows. The bulk etch rate was the highest in the case of the highest temperature, i.e., $90^{\circ} \mathrm{C}-$ as expected, according to the literature. The deviation of the $V_{B}$ for the same temperature and for different times of etching was lower at the highest temperature and higher at lower temperatures. The average values of the bulk etch rates are shown in Fig. 4. These values were calculated from the particular etch velocities in the case of a different etching time. 


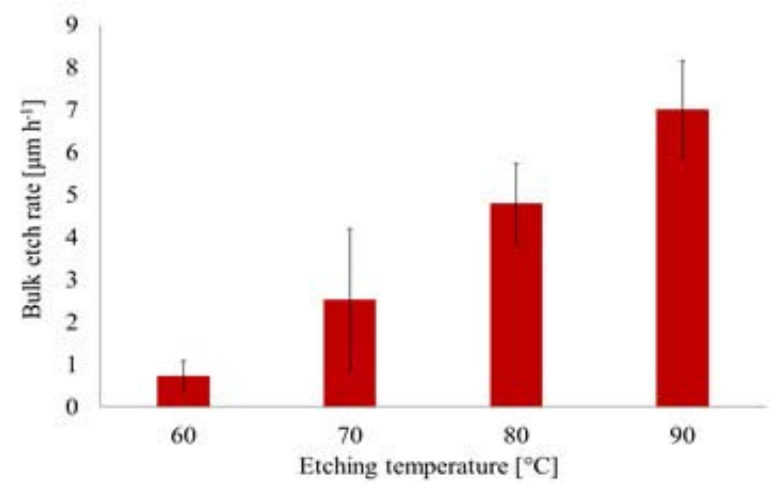

Fig. 4. Bulk etch rates at different temperatures.

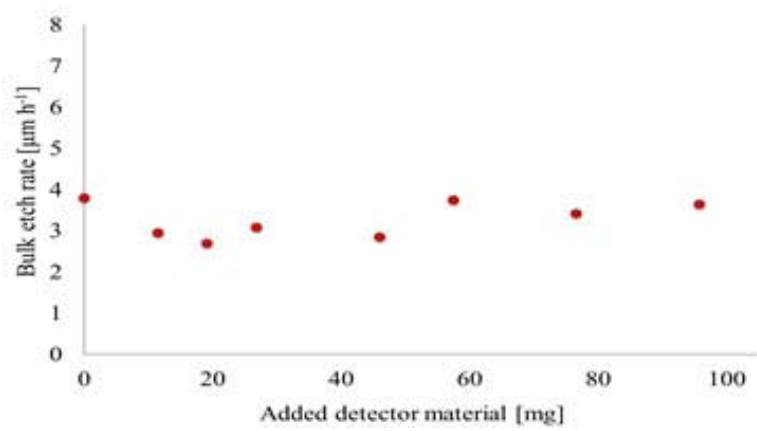

Fig. 5. Testing the reuse potential of the etching solution.

Table 1. Average track diameters for different times at $90^{\circ} \mathrm{C}$

\begin{tabular}{lcccccc}
\hline Etching time $[\mathrm{h}]$ & 3 & 4 & 5 & 6 & 7 & 8 \\
Track diameter $[\mu \mathrm{m}]$ & 14 & 23 & 28 & 33 & 38 & 45 \\
\hline
\end{tabular}

To check the ingrowth of the tracks during the etching time, the detectors - which were etched at the temperature of $90^{\circ} \mathrm{C}$ - were investigated by scanning electron microscope (SEM). The average track diameter can be seen in Table 1 . The optimal range for the new system is $40-60 \mu \mathrm{m}$, which was reached after 8 hours of etching.

Due to the possibility of shortening the etching time using a mixture of the reused etching solution, etching of the detectors in solutions with different amounts of reused solutions was done. The result of the etching solution's reuse can be seen in Fig. 5.

As can be seen in the figure, the added detector material did not increase the etching velocity. Based on these results, it can be stated that the reuse of the solution would not cause any changes in etching time, but reuse is not suggested because of the other possible confounding parameters (such as $\mathrm{CO}_{2}$ ), which were not investigated in this study.

\section{Conclusions}

To be used in the required indoor radon surveys and considering the reference level set in the EU-BSS Directive, reliable track detectors with low background are necessary. Therefore, two different types of CR-39 track detectors (Baryotrak and Tastrak) were investigated. The most important parameters were the background track density and detector's response to radon, which were tested over a 1-year period. Based on the results, the Baryotrak detectors are recommended for use in surveys because of their lower background track density and smaller deviation of the calibration factor.

After the systematic review of the etching system, a new etching method was developed to ensure the quality of the whole procedure. At first, the special calibration sheet for the determination of the range of optimal track diameters for the new scanning system was prepared by using ArF laser. It has been found that the optimum range for the track diameter of the new system was $40-60 \mu \mathrm{m}$. On this basis, new etching conditions were determined to achieve the required range of track diameter: the solution for etching was $6.25 \mathrm{M} \mathrm{NaOH}$, the temperature of etching was $90^{\circ} \mathrm{C}$, and the etching time was $8 \mathrm{~h}$. The possibility of reuse of the etching solution was also investigated. It was observed that the etching velocity was not influenced by the concentration of the etching products in the solution, but reuse of the solution is not recommended because of other confounding parameters.

Acknowledgment. This study was supported by the Hungarian National Research OTKA grant numbers K128805 and K128818.

\section{ORCID}

A. Csordás (1Dhttp://orcid.org/0000-0002-7235-5922

T. Kovács (D http://orcid.org/0000-0003-2606-0397

E. Tóth-Bodrogi (D) http://orcid.org/0000-0002-4135-7925

\section{References}

1. United Nations Scientific Committee on the Effects of Atomic Radiation. (2000). Sources and effects of ionizing radiation. United Nations Scientific Committee on the Effects of Atomic Radiation UNSCEAR 2000 Report to the General Assembly, with Scientific Annexes. Vol. 1: Sources. New York: United Nations.

2. Podstawczyńska, A., \& Pawlak, W. (2016). Soil heat flux and air temperature as factors of radon (Rn-222) concentration in the near-ground air layer. Nukleonika, 61(3), 231-237. DOI: 10.1515/nuka-2016-0039.

3. Gregorič, A., Vaupotič, J., Kardos, R., Horváth, M., Bujtor, T., \& Kovács, T. (2013). Radon emanation of soils from different lithological units. Carpath. J. Earth Environ. Sci., 8(2), 185-190.

4. Chalupnik, S., \& Wysocka, M. (2003). Measurement of radon exhalation from soil - development of the method and preliminary results. $J$. Mining Sci., 39, 191-198. https://doi.org/10.1023/ B:JOMI.0000008467.53630.09.

5. Wysocka, M., Kotyrba, A., Chalupnik, S., \& Skowronek, J. (2005). Geophysical methods in radon risk studies. J. Environ. Radioact., 82(3), 351-362. DOI: 10.1016/j.jenvrad.2005.02.009. 
6. Kovács, T., Shahrokhi, A., Sas, Z., Vigh, T., \& Somlai, J. (2017). Radon exhalation study of manganese clay residue and usability in brick production. J. Environ. Radioact., 168, 15-20. https://doi.org/10.1016/j. jenvrad.2016.07.014.

7. Sas, Z., Somlai, J., Szeiler, G., \& Kovács, T. (2015). Usability of clay mixed red mud in Hungarian building material production industry. J. Radioanal. Nucl. Chem., 306(1), 271-275. https://doi.org/10.1007/ s10967-015-3966-z.

8. Wieprzowski, K., Bekas, M., Waśniewska, E., Wardziński, A., \& Magiera, A. (2018). Radon ${ }^{222} \mathrm{Rn}$ in drinking water of West Pomeranian Voivodeship and Kuyavian-Pomeranian Voivodeship, Poland. Nukleonika, 63(2), 43-46. DOI: 10.2478/nuka-2018-0005.

9. Jobbágy, V., Altzitzoglou, T., Malo, P., Tanner, V., \& Hult, M. (2017). A brief overview on radon measurements in drinking water. J. Environ. Radioact., 173, 18-24. https://doi.org/10.1016/j.jenvrad.2016.09.019.

10. Dixon, D. W. (2001). Radon exposures from the use of natural gas in buildings. Radiat. Prot. Dosim., 97(3), 359-364. DOI: 10.1093/oxfordjournals.rpd.a006671.

11. European Union. (2013). Council Directive 2013/59/ Euratom of 5 December 2013 laying down basic safety standards for protection against the dangers arising from exposure to ionising radiation, and repealing Directives 89/618/Euratom, 90/641/Euratom, 96/29/ Euratom, 97/43/Euratom and 2003/122/Euratom. Official Journal of the European Union, OJ L13, 17.1.2014, 1-73. https://eur-lex.europa.eu/legalcontent/EN/TXT/?uri=OJ:L:2014:013:TOC.

12. Somogyi, Gy., Nikl, I., Csige, I., \& Hunyadi, I. (1989). Radon aktivitáskoncentrációjánakméréseés a belég zésbőleredősugárterhelésmeghatározásahazailakás oklégterében. Izotóptechnika, diagnosztika, 32(4), 177-183.

13. Nikl, I. (1996). The radon concentration and absorbed dose rate in Hungarian dwellings. Radiat. Prot. Dosim., 67(3), 225-228. https://doi.org/10.1093/ oxfordjournals.rpd.a031821.

14. International Commission on Radiological Protection. (1993). Protection against radon-222 at home and at work. (ICRP Publication 65). Ann. ICRP, 23(2).

15. Hámori, K., Tóth, E., Lénárd, P., Köteles, G., Losonci, A., \& Minda, M. (2006). Evaluation of indoor radon measurements in Hungary. J. Environ. Radioact., 88, 189-198. https://doi.org/10.1016/j. jenvrad.2006.02.002.
16. Szeiler, G., Somlai, J., Ishikawa, T., Omori, Y., Mishra, R., Sapra, B. K., Mayya, Y. S., Tokonami, S., Csordás, A., \& Kovács, T. (2012). Preliminary results from an indoor radon thoron survey in Hungary. Radiat. Prot. Dosim., 152, 243-246. DOI: 10.1093/rpd/ncs231.

17. Müllerova, M., Kozak, K., Kovács, T., Csordás, A., Grzadziel, D., Holy, K., Mazur, J., Moravcsík, A., Neznal, Matej, Neznal, Martin, \& Smetanova, I. (2014). Preliminary results of indoor radon survey in V4 countries. Radiat. Prot. Dosim., 160(1/3), 210-213. https://doi.org/10.1093/rpd/ncu081.

18. Müllerova, M., Kozak, K., Kovács, T., Smetanova, I., Csordás, A., Grzadziel, D., Holy, K., Mazur, J. Moravcsík, A., Neznal, Martin, \& Neznal, Matej (2016). Indoor radon survey in Visegrad countries. Appl. Radiat. Isot., 110, 124-128. https://doi. org/10.1016/j.apradiso.2016.01.010.

19. Müllerova, M., Mazur, J., Csordás, A., Grzadziel, D., Holy, K., Kovács, T., Kozak, K., Kurekova, P., Nagy, E., Neznal, M., \& Smetanova, I. (2017). Preliminary results of radon survey in the kindergartens of V4 countries. Radiat. Prot. Dosim., 177(1/2), 95-98. https://doi.org/10.1093/rpd/ncx155.

20. Csordás, A., Bátor, G., Horváth, D., Somlai, J., \& Kovács, T. (2016). Validation of the scanner based radon track detector evaluation system. Radiat. Meas., 87, 1-7. https://doi.org/10.1016/j. radmeas.2016.02.011.

21. Nikezic, D., \& Yu, K. N. (2004). Formation and growth of tracks in nuclear track materials. Mater. Sci. Eng., 46, 51-123. https://doi.org/10.1016/j. mser.2004.07.003.

22. Matiullah, , Rehman, S., Rehman, S., Mati, N., \& Ahmad, S. (2005). Some more new etchants for CR-39 detector. Radiat. Meas., 39, 551-555. DOI: 10.1016/j. radmeas.2004.10.009.

23. Ashry, A. H., Abdalla, A. M., Rammah, Y. S., Eisa, M., \& Ashraf, O. (2014). The use of $\mathrm{CH}_{3} \mathrm{OH}$ additive to $\mathrm{NaOH}$ for etching alpha particle tracks in a CR-39 plastic nuclear track detector. Radiat. Phys. Chem., 101, 41-45. https://doi.org/10.1016/j.radphyschem.2014.03.037.

24. Bátor, G., Csordás, A., Horváth, D., \& Kovács, T. (2015). A comparison of a track shape analysis-based automated slide scanner system with traditional methods. I. Radioanal. Nucl. Chem., 306(1), 333-339. https://doi.org/10.1007/s10967-015-4013-9. 